\title{
Decline of endemic Oncocyclus irises (Iridaceae) of Lebanon: survey and conservation needs
}

\author{
Layla SAa D, Salma N. Talhouk and Grégory Mahy
}

\begin{abstract}
The endemic Oncocyclus irises of Lebanon are rare and threatened. Their historical locations (based on information from herbaria and the available literature) were compared to an update of their current distribution. Only $50 \%$ of the previously known populations were confirmed extant, indicating a considerable decline in the range of these taxa. The populations that were relocated were either small remnants of once larger populations or highly fragmented. The main threats identified were urbanization, agriculture and grazing. No specific habitat preferences could be identified other than an association with open rocky slopes with a south-west exposure. Based on our findings, we propose that Iris cedretii and Iris sofarana subsp. sofarana should be categorized as Endangered on the IUCN Red List and I. sofarana subsp. kasruwana as Vulnerable. There is an urgent need to develop national conservation measures for these species, especially in regards to land ownership.
\end{abstract}

Keywords Endemic, Iridaceae, Iris, Lebanon, Oncocyclus, Red List.

\section{Introduction}

The Global Strategy for Plant Conservation (2008) aims to halt the continuing loss of plant diversity. Understanding, documenting and developing conservation strategies for plant species are key issues that need to be urgently addressed as national responsibilities (UNEP, 2005). In Lebanon, floristic richness is estimated to include 2,600 vascular plant species of which $311(12 \%)$ are endemic (Khouzami et al., 1996).

In the genus Iris 53 taxa are threatened worldwide, of which 29 belong to the section Oncocyclus (Walter \& Gillet, 1998). Oncocyclus irises bear large showy flowers and have long fascinated horticulturists (Foster, 1899). They are xerophytic plants growing naturally in the Caucasus, eastern Turkey, Syria, Lebanon, Jordan and Israel, and further to the east in Iraq, Iran and Afghanistan (Matthew, 1989; Rix, 1997). Flower picking and collection of whole plants was probably one of the first causes of human pressure on

\footnotetext{
LAYla SAAD (Corresponding author) and GrÉgory Mahy Ecology Laboratory, Gembloux Agricultural University, Passage des Déportés 2, B-5030 Gembloux, Belgium. E-mail saad.l@fsagx.ac.be

Salma N. Talhouk Department of Plant Sciences, Faculty of Agricultural and Food Sciences, American University of Beirut, Lebanon.

Received 26 February 2007. Revision requested 4 August 2007. Accepted 28 November 2007.
}

wild Oncocyclus populations. The first mention of Oncocyclus cultivation dates from the 4th century BC when the Egyptian Pharaoh Tutmosis III brought plants back from his expedition in Asia (Archibald, 1999). At the beginning of the 2oth century rhizomes were heavily collected in the wild from Turkey and the Middle East to be sold in Western Europe (Archibald, 1999). Awareness of the need to conserve Oncocyclus irises has been highlighted in several countries. In Jordan, for example, the black iris I. nigricans is the national flower, and the so-called Royal irises have become the symbol of nature protection in Israel. Some iris taxa are protected in Turkey (I. sprengeri) and Armenia (I. paradoxa; Gazit-Ginsburg, 1974; Archibald, 1999; Shmida et al., 2002; Tan et al., 2003).

The Lebanese endemic Oncocyclus irises (I. cedretii, I. sofarana subsp. kasruwana, I. sofarana subsp. sofarana and I. westii) are rare, growing along the country's western mountain chain. In Lebanon no national conservation measures have yet been undertaken to protect Oncocyclus irises or any other plant species except those occurring within nature reserves (MOE, 2001), and only $2.5 \%$ of Lebanon's mountainous area, the natural range of Lebanese Oncocyclus irises, is protected by nature reserves (Khouzami et al., 1996; Samaha, undated).

The aim of the research reported here was to examine the contemporary distribution of the Oncocyclus irises of Lebanon in comparison to the known historical distribution of the taxa, identifying their habitats and the threats to the remaining populations, and assessing their conservation status.

\section{Methods}

Historical distributions were determined using a literature and herbarium-based survey supplemented by contacts with individuals familiar with Lebanon's flora. The consulted literature included Floras, books on the genus Iris, and original descriptions of the taxa (Foster, 1899; Post, 1933; Dinsmore, 1934; Mouterde, 1966; Chaudhary, 1972, 1974; Kohlein, 1987; Mathew, 1989; Rix, 1997; Tohmé \& Tohmé, 2001). The herbaria with significant collections of Lebanese Oncocyclus are the Post Herbarium at the American University of Beirut, Lebanon (BEI), the Royal Botanical Gardens, Kew, UK (K), and Geneva, Switzerland (G). Actual specimens were examined at BEI and $\mathrm{K}$, and electronic images were sent from G. All extant information was recorded for each specimen. 
TABLE 1 Locations of the four taxa of endemic Oncocyclus irises in Lebanon as determined from literature and herbarium specimens, with the number of times the locations were cited in published literature, the number of specimens in herbaria, and the current status of the populations as determined by the field surveys.

\begin{tabular}{|c|c|c|c|c|}
\hline Taxon & Location & $\begin{array}{l}\text { Times cited } \\
\text { in literature }\end{array}$ & $\begin{array}{l}\text { No. of } \\
\text { herbarium } \\
\text { specimens }\end{array}$ & Status $^{*}$ \\
\hline \multirow[t]{3}{*}{ Iris cedretii Dinsm. ex Chaudhary } & Vicinity of the Cedars & 5 & 10 & PC \\
\hline & Between Ehden and the Cedars (Ain El Haramieh) & 1 & 0 & $\mathrm{PC}$ \\
\hline & Vicinity of Hasroun & 1 & 0 & $\mathrm{AC}$ \\
\hline \multirow[t]{5}{*}{ Iris sofarana subsp. sofarana Foster } & Dahr el Baidar & 2 & 22 & NF \\
\hline & Col Zahlé/Hazerta & 1 & 0 & NF \\
\hline & Qartaba & 1 & 0 & $\mathrm{AC}$ \\
\hline & Falougha (Kneissé) & 2 & 4 & $\mathrm{PC}$ \\
\hline & Sofar & 2 & 0 & $\mathrm{PC}$ \\
\hline \multirow[t]{2}{*}{ Iris sofarana subsp. kasruwana Dinsm. } & Nab’ el Aasal/Faraya & 6 & 2 & $\mathrm{PC}$ \\
\hline & Laqlouq & 3 & 1 & $\mathrm{PC}$ \\
\hline \multirow[t]{2}{*}{ Iris westii Dinsm. } & Jezzine/Tawmat Niha & 5 & 6 & $?$ \\
\hline & Machgarat/Aytanit & 3 & 2 & $?$ \\
\hline
\end{tabular}

${ }^{*} \mathrm{AC}$, absence confirmed; PC, presence confirmed; NF, not found; ?, not visited

We surveyed for irises in May 2002 and 2003, i.e. in the flowering period, for a total of 26 days. Surveyed areas were chosen based on information archived with herbarium specimens and in the literature. Using the road network for access, we walked within high altitude rocky areas that appeared to have habitat suitable for irises. Depending on the size of the area, 1-3 days were spent in each location. When a population was located an additional 1-2 days were spent to determine the extent of the population, walking extensively in an area of at least $1 \mathrm{~km}^{2}$ around each population.

Located populations were divided subjectively into subpopulations based on their relative isolation (distance, presence of natural or artificial barriers) and habitat type (topography, soil and dominant vegetation). We estimated the number of individuals in each population (by counting individuals along transects in sub-populations and multiplying mean density by the effectively occupied area, and then by summing the results for all sub-populations within a population). The apparent geographical limits of each sub-population were mapped with a global positioning system (at least four locations per sub-population) and the area estimated using the geographical system ArcView v. 3.2 (ESRI, Redlands, USA). For each sub-population we noted slope of the land, aspect, soil type (1, reddish brown; 2 , yellowish brown; 3 , greyish brown), whether there was $>50 \%$ surface rock cover, and whether the soil had a sandy texture.

The current or potential pressures on populations in general and on each sub-population in particular were determined based on: (1) Direct observations (urbanization, cultivation, presence of grazing flocks or observation of animal tracks or faeces). (2) Communication with local people (all the people living within the sites or in immediately adjacent areas were questioned about land ownership, historical and current land use and future housing projects in the area; we met at least one council member for each site). (3) Consultation of urbanism/cadastral maps (available from the town planning department of each county) to determine the ownership and status of the sites (private vs council lands, building vs natural zones).

Using the information collected, the IUCN Red List status (IUCN, 2001) of each taxon was assessed.

\section{Results}

Published records indicated that populations were formerly present in 12 known locations on Mount Lebanon (Table 1). Collection dates indicate few and sporadic collection efforts, mostly during 1930-1972 (Table 2). The oldest herbarium specimen is from 1880 (in BEI). There are relatively few specimens per taxon and even when specimens are numerous, they are from a limited number of collections (Table 2). Ecological data associated with herbarium specimens were limited: altitude, habitat and soil type were noted for only $8 \%$ of the specimens. Eighty-seven per cent of the specimens have a collection date and location but only vague locality indications are given, and data on the extent of the populations were not given.

We were able to confirm presence of irises in six of the 12 previously reported sites (Table 1, Fig. 1). Two populations could not be relocated and are probably extinct (I. cedretii in the vicinity of Hasroun, and I. sofarana subsp. sofarana in Qartaba) as no irises were found within $5 \mathrm{~km}$ around the supposed locations of the species and as disturbances such as agriculture and urbanization are significant causes of habitat loss in these areas. One population requires further field surveys given the large scale of the area (I. sofarana subsp. sofarana in the Zahlé-Hazerta pass), and three 
TABLE 2 Number of specimens and collectors, and year of first and last collection, for the herbarium collections of Lebanese Oncocyclus irises.

\begin{tabular}{lllll}
\hline Taxon & $\begin{array}{l}\text { No. of } \\
\text { specimens }\end{array}$ & $\begin{array}{l}\text { No. of } \\
\text { collectors }\end{array}$ & $\begin{array}{l}\text { Year of first } \\
\text { collection }\end{array}$ & $\begin{array}{l}\text { Year of last } \\
\text { collection }\end{array}$ \\
\hline I. cedretii & 10 & 4 & 1880 & 1972 \\
I. sofarana subsp. sofarana & 26 & 6 & 1950 & 1972 \\
I. sofarana subsp. kasruwana & 3 & 3 & 1940 & 1956 \\
I. westii & 8 & 3 & 1930 & 1965 \\
\hline
\end{tabular}

populations (I. sofarana subsp. sofarana population in Dahr El Baidar and two I. westii populations in the south) could not be visited for safety reasons, including possible presence of land mines.

The six located populations vary in extent from $500 \mathrm{~m}^{2}$ to $>4$ ha, contain from 15 to $>3,000$ individuals, occur at altitudes of 1,350-1,900 $\mathrm{m}$, and grow preferentially on rocky slopes (up to $30^{\circ}$ ) with a south/south-west exposure (Table 3 ). No specific relationships were detected with soil type. All populations are located in highly disturbed environments and are facing a variety of threats (Table 3 ). Urbanization is a serious threat for all populations. Agricultural expansion is the second most serious cause of habitat loss. Grazing by sheep and goats is frequent but its impact on the populations seems to be low. Other pressures include flower picking and, on one site, the presence of old sand quarries.

According to the consulted cadastral maps, all existing iris populations are located on private land and at least two of the largest populations (the Cedars and Nab' El Aasal) are located on land that has been divided into plots for sale. Iris populations cover, respectively, 13 plots in the Cedars and 27 in Nab' El Aasal (MOF, undated; MOPW, undated).

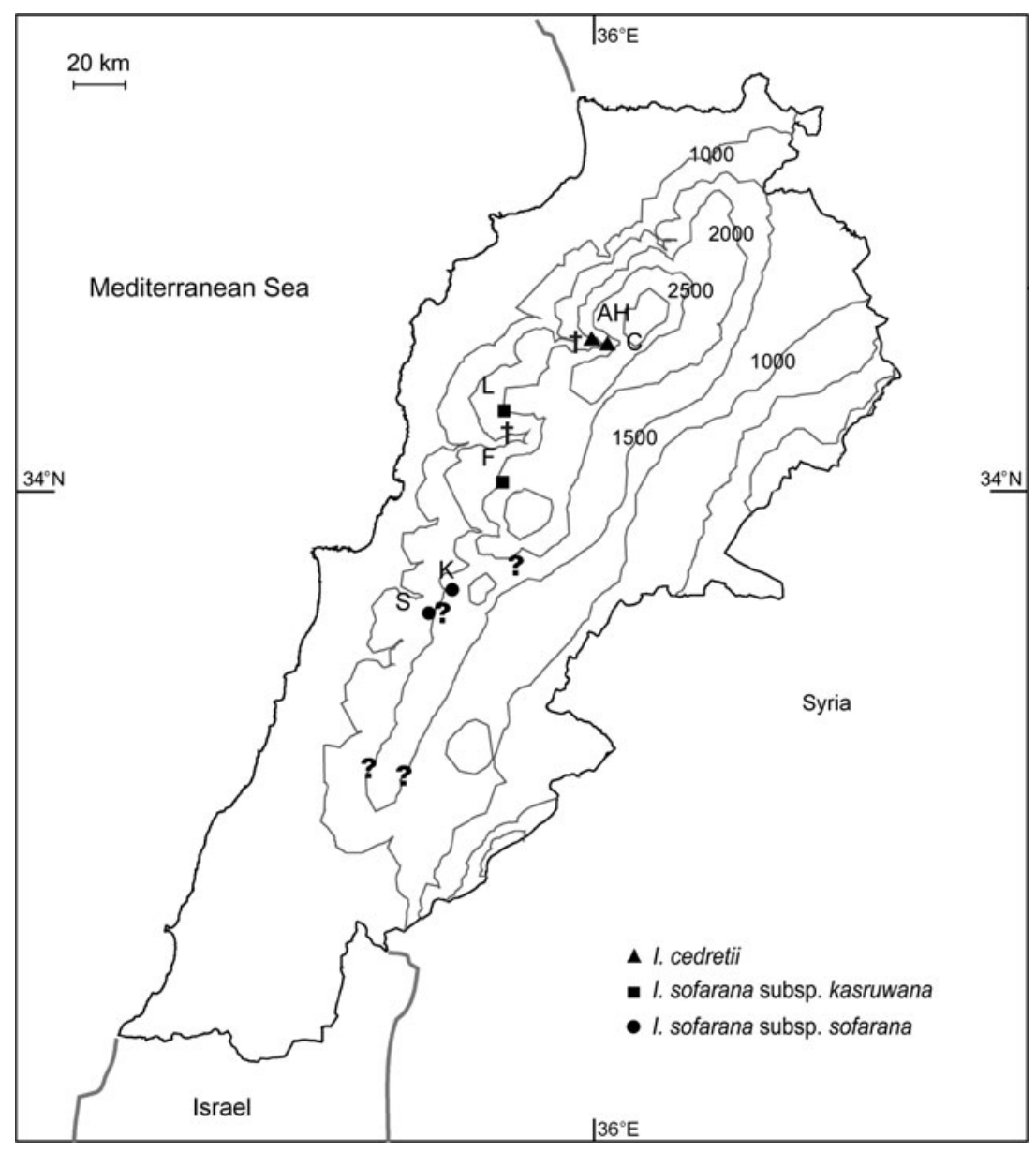

FIg. 1 The known distribution of the populations of endemic Oncocyclus irises in Lebanon. Letters represent populations (Table 3): AH, Ain El Haramieh; C, The Cedars; L, Laqlouq; F, Faraya; K, Kneissé; S, Sofar; †, populations for which extirpation was confirmed; ?, populations not located or not visited. 
TABLE 3 Area of occurrence of the located sub-populations and estimated total numbers in each population of the endemic Lebanese Oncocyclus irises (we were unable to visit the locations of $I$. westii), with altitude, slope, aspect and soil type in the area of each sub-population or population and identified threats to each sub-population or population.

\begin{tabular}{|c|c|c|c|c|c|c|c|c|}
\hline Location & $\begin{array}{l}\text { Population/ } \\
\text { sub-population }\end{array}$ & $\begin{array}{l}\text { Area } \\
\left(\mathrm{m}^{2}\right)\end{array}$ & No. ${ }^{1}$ & $\begin{array}{l}\text { Altitude } \\
(\mathrm{m})\end{array}$ & $\begin{array}{l}\text { Slope } \\
\left({ }^{\circ}\right)\end{array}$ & Aspect & Soil type ${ }^{2}$ & Threats \\
\hline \multicolumn{9}{|l|}{ I. cedretii } \\
\hline \multirow[t]{9}{*}{ The Cedars } & $\mathrm{C} 1$ & 8,000 & $>2,000$ & 1,860 & 25 & $S$ & $1 \mathrm{r}$ & $\begin{array}{l}\text { Potential urbanization, } \\
\text { grazing, road }\end{array}$ \\
\hline & $\mathrm{C} 2$ & 3,500 & & 1,860 & 25 & SW & $2 \mathrm{r}$ & $\begin{array}{l}\text { Potential urbanization, } \\
\text { grazing }\end{array}$ \\
\hline & C3 & 1,000 & & 1,840 & 20 & SW & 1 & $\begin{array}{l}\text { Potential urbanization, } \\
\text { grazing }\end{array}$ \\
\hline & $\mathrm{C} 4$ & 2,000 & & 1,890 & & & 1 & $\begin{array}{l}\text { Potential urbanization, } \\
\text { grazing }\end{array}$ \\
\hline & C5 & 1,500 & & 1,850 & 30 & SW & $1 \mathrm{r}$ & $\begin{array}{l}\text { Urbanization, road, } \\
\text { flower picking }\end{array}$ \\
\hline & C6 & 1,000 & & 1,860 & 30 & S & $1+2 \mathrm{r}$ & $\begin{array}{l}\text { Potential urbanization, } \\
\text { grazing, herbivory }\end{array}$ \\
\hline & $\mathrm{C} 7$ & 1,000 & & 1,890 & & & $1 \mathrm{r}$ & $\begin{array}{l}\text { Potential urbanization, } \\
\text { grazing, dirt track, } \\
\text { agriculture }\end{array}$ \\
\hline & $\mathrm{C} 8$ & 1,000 & & 1,830 & & & 1 & Road, flower picking \\
\hline & C9 & 3,000 & & 1,830 & & & 1 & Road, urbanization \\
\hline $\begin{array}{l}\text { Between Ehden \& } \\
\text { the Cedars (Ain el } \\
\text { Haramieh) }\end{array}$ & $\mathrm{AH}$ & 500 & 200 & 1,840 & 15 & SW & $1+2 \mathrm{r}$ & Agriculture, dirt track \\
\hline \multicolumn{9}{|c|}{ I. sofarana subsp. sofarana } \\
\hline Falougha (Kneissé) & K & 1,500 & 50 & 1,800 & 20 & $S$ & $1 \mathrm{r}$ & $\begin{array}{l}\text { Herbivory, grazing, potential } \\
\text { urbanization }\end{array}$ \\
\hline Sofar & $\mathrm{S}$ & 500 & 15 & 1,350 & 30 & SE & $1 \mathrm{r}$ & Urbanization, herbivory \\
\hline \multicolumn{9}{|c|}{ I. sofarana subsp. kasruwana } \\
\hline \multirow[t]{7}{*}{ Nab el Aasal/Faraya } & $\mathrm{F} 1$ & 10,000 & $>1,000$ & 1,560 & 20 & SSW & $1+2$ & $\begin{array}{l}\text { Urbanization, road, dump, } \\
\text { agriculture, grazing }\end{array}$ \\
\hline & $\mathrm{F} 2$ & 600 & & 1,610 & 25 & SW & $1 \mathrm{r}$ & $\begin{array}{l}\text { Potential urbanization, } \\
\text { grazing, dirt track }\end{array}$ \\
\hline & $\mathrm{F} 3$ & 10,000 & & 1,610 & 30 & S & $1+2 \mathrm{r}$ & $\begin{array}{l}\text { Potential urbanization, } \\
\text { agriculture }\end{array}$ \\
\hline & $\mathrm{F} 4$ & 75 & & 1,600 & & & 1 & $\begin{array}{l}\text { Potential urbanization, } \\
\text { agriculture }\end{array}$ \\
\hline & F5 & 400 & & 1,680 & & & $1+2$ & $\begin{array}{l}\text { Potential urbanization, } \\
\text { grazing, dirt track }\end{array}$ \\
\hline & F6 & 400 & & 1,640 & 20 & SW & 2 & $\begin{array}{l}\text { Potential urbanization, } \\
\text { grazing, dirt track }\end{array}$ \\
\hline & F7 & 200 & & 1,600 & 25 & SSE & $1 \mathrm{r}$ & $\begin{array}{l}\text { Potential urbanization, } \\
\text { agriculture, roads }\end{array}$ \\
\hline \multirow[t]{7}{*}{ Laqlouq } & $\mathrm{L} 1$ & 50 & $>3,000$ & 1,530 & & $\mathrm{~N}$ & 1 & Grazing, road, dump \\
\hline & $\mathrm{L} 2$ & 1,000 & & 1,560 & 20 & SW & $2 \mathrm{~s}$ & Grazing \\
\hline & L3 & 1,950 & & 1,560 & 20 & SW & 3 rs & Grazing \\
\hline & $\mathrm{L} 4$ & 1,000 & & 1,540 & & & 1 & Grazing, quarry \\
\hline & L5 & 175 & & 1,580 & & & 1 & $\begin{array}{l}\text { Urbanization, grazing, } \\
\text { dirt track, dump }\end{array}$ \\
\hline & L6 & 300 & & 1,570 & 10 & S & $1 \mathrm{~s}$ & $\begin{array}{l}\text { Grazing, goat enclosure, } \\
\text { dirt track }\end{array}$ \\
\hline & L7 & & & $1,550-1,600$ & & SW & $1+3 \mathrm{rs}$ & $\begin{array}{l}\text { Grazing (traditional + cow } \\
\text { grazing), dirt track, dump }\end{array}$ \\
\hline
\end{tabular}

${ }^{1}$ Clumps or potential genets

${ }^{2}$, reddish brown; 2, yellowish brown; 3, greyish brown; r, rocky; s, sandy 
Based on our findings, including extent of occurrence, area of occupancy, population size, number of locations and projected decline, we propose Red List categorizations of Endangered for I. cedretii (based on criteria Brab(ii,iv)+ $2 \mathrm{ab}(\mathrm{ii}, \mathrm{iv}))$ and I. sofarana subsp. sofarana (B1ab(ii,iv) $+2 \mathrm{ab}$ (ii,iv), D)) and Vulnerable for I. sofarana subsp. kasruwana $\left(\mathrm{A}_{4} \mathrm{c}+\mathrm{B} 1 \mathrm{ab}(\mathrm{ii})\right)$.

\section{Discussion}

Herbaria often provide valuable information on the historical distribution of species. For the Oncocyclus irises of Lebanon herbaria include $58 \%$ of the historical information and are representative of $66 \%$ of the extant populations. The location of populations is better documented in the literature than in herbaria, however. Our fieldwork indicates a decline in the populations of these irises, with two populations apparently extirpated and two that may have disappeared out of the 12 historically reported, and we did not locate any previously unknown populations.

Ecological data associated with herbarium specimens were limited, with only $4-8 \%$ including data concerning altitude, habitat and/or soil type, which is typical for herbarium specimens (Dulloo et al., 1999). We did not identify any specific habitat requirements except preference for good soil drainage, reflected in occurrence on rocky sloping sites with a southern exposure. Irises colonize different types of soils and no soil differences were found between areas harbouring irises compared to areas where they were absent (Saad, 2006). There are examples of adaptation of Oncocyclus to specific soil types, such as Iris basaltica (West, 1963), which grows on basalt, but no such specificity is apparent in the Oncocyclus group in Lebanon. Oncocyclus irises appear to grow only at high altitudes in Lebanon but in adjacent areas in Jordan and Israel some species occur down to sea level (Rix, 1997).

The major threat to iris populations in Lebanon is habitat loss due to the expansion of winter resorts and associated infrastructure such as new road networks and buildings. Tourism and recreational activities are the main threat to ecosystems throughout the Mediterranean (Allen, 2001; Bennett \& Bullitta, 2003). Human activity typically leads to fragmentation of suitable habitat (Gibbs, 2001). Populations of Lebanese Oncocyclus irises are fragmented and/or represent the remnants of larger historical populations. The consequences of fragmentation are reductions in the number of breeding individuals within a population, and reduced gene flow between populations (Dudash \& Fenster, 2000) and pollination efficiency (Duncan et al., 2004). The small size of remnant populations makes them more prone to demographic, environmental and genetic stochasticity (Fisher \& Matthies, 1998; Lande, 1998; Oostermeijer et al., 2003). Herbivory by caterpillars and phytophageous insects at flowering time has most likely inhibited chances of sexual reproduction in the populations of Sofar and Kneissé, and has negatively impacted the reproductive potentials of the population in Ain El Haramieh (Saad, 2006). We observed that grazing by domestic goats and sheep is a threat to Oncocyclus irises only when the seed pods are green and fleshy, although Arafeh et al. (2002) reported grazing on all parts of the plant.

All existing iris populations are located on private land and, given the fact that there is currently no legal framework in Lebanon for the protection of either irises or other plant species in general on private lands, intervention such as translocation of populations will need to be considered. No ex situ conservation facilities exist in Lebanon and none of the Lebanese Oncocyclus irises are currently growing in international botanical gardens. The only place where they can be found is the Millennium Seed Bank (Wakehurst Place, Botanic Gardens Kew, UK) where I. cedretii and I. sofarana subsp. kasruwana seeds are preserved.

This study of Oncocyclus irises is an example of the type of conservation research that is required for the flora of Lebanon. Our findings have been passed to the Ministry of Environment, which is drafting a law that will oblige land owners to carry out an ecological impact assessment when applying for a building permit (C. Khater, pers. comm.). However, such a legal statute cannot insure the long-term preservation of these endemic irises. Data gathering about distributions, limiting environmental factors and the impact of human activity is a first step towards the conservation of rare plant species (Dinsdale et al., 1997). Additional research on taxonomy, population dynamics and genetics allowed us to define conservation units for these taxa more accurate (Monty et al., 2006; Saad, 2006), and propagation techniques that could be used for restoration have been studied at the American University of Beirut (L. Saad \& S.N. Talhouk, unpubl. data).

\section{Acknowledgements}

We thank D. West and Y. Tawk for location indications and A. Saad for help during the fieldwork. We thank the curators of the herbaria at Post, Beirut, Lebanon, Royal Botanic Gardens Kew, UK, and Geneva, Switzerland. LS benefited from a grant from the Belgian Fonds pour la Recherche dans l'Industrie et l'Agriculture.

\section{References}

Allen, H.D. (2001) Mediterranean Ecogeography. Pearsons Education, Harlow, UK.

Arafeh, R.M.H., Sapir, Y., Shmida, A., Iraki, N., Fragman, O. \& Comes, H.P. (2002) Patterns of genetic and phenotypic variation in Iris haynei and I. atrofusca (Iris sect. Oncocyclus = the Royal Irises) along an environmental gradient in Israel and the West Bank. Molecular Ecology, 11, 39-53. 
Archibald, J. (1999) Silken sad uncertain queens. Bulletin of the Alpine Garden Society, 67, 245-264.

Bennett, S.A. \& Bullitta, S. (2003) Ecogeographical analysis of the distribution of six Trifolium species in Sardinia. Biodiversity and Conservation, 12, 1455-1466.

Chaudhary, S.A. (1972) Three new taxa of Iris subgenus Oncocyclus from Lebanon and Syria. Bot Notiser, 125, 497-500.

Chaudhary, S.A. (1974) Taxonomy of Oncocyclus irises from Lebanon and Syria. ASI Yearbook, 1974, 65-68.

Dinsdale, J., Dale, P. \& Kent, M. (1997) The biogeography and historical ecology of Lobelia urens L. (the heath lobelia) in southern England. Journal of Biogeography, 24, 153-175.

Dinsmore, J.E. (1934) Plantae Postianae et Dinsmoreanae. Vol. 2. American University Press, Beirut, Lebanon.

DUDASh, M.R. \& Fenster, C.B. (2000) Inbreeding and outbreeding depression in fragmented populations. In Genetics, Demography and Viability of Fragmented Populations (eds A. Young \& G. Clarke), pp. 35-53. Cambridge University Press, Cambridge, UK.

Dulloo, M.E., Maxted, N., Guarino, L., Florens, D., Newbury, H.J. \& Ford-Lloyd, B.V. (1999) Ecogeographic survey of the genus Coffea in the Mascarene Islands. Botanical Journal of the Linnean Society, 131, 263-284.

Duncan, D.H., Nicotra, A.B., Wood, J.T. \& Cunningham, S.A. (2004) Plant isolation reduces outcross pollen receipt in a partially self-compatible herb. Journal of Ecology, 92, 977-985.

Fisher, M. \& Matthies, D. (1998) Effects of population size on performance in the rare plant Gentianella germanica. Journal of Ecology, 86, 195-204.

Foster, M. (1899) Iris sofarana n. sp.. The Gardener Chronicle, II, 389.

Gazit-Ginsburg, Z. (1974) The Oncocyclus irises in their connection with the phytogeographical territories of Israel. ASI Yearbook, 1974, 76-81.

Gibis, J.P. (2001) Demography versus habitat fragmentation as determinants of genetic variation in wild populations. Biological Conservation, 100, 15-20.

Global Strategy for Plant Conservation (2008) Http://www.cbd.int/ gspc/ [accessed 24 June 2008].

IUCN (2001) 2001 Categories and Criteria (version 3.1). IUCN, Gland, Switzerland [http://www.redlist.org/info/categories_ criteria2001.html, accessed 8 April 2008].

IUCN (2007) 2007 IUCN Red List of Threatened Species. IUCN, Gland, Switzerland. Http://www.iucnredlist.org [accessed 28 September 2007].

Khouzami, M., Bassil, M., Fortunat, L. \& Hayek, A. (1996) Etude de la diversité biologique du Liban. Ministry of Agriculture \& UNEP, Beirut, Lebanon.

Kohlein, F. (1987) Iris. Timber Press, Portland, Oregon.

LAnde, R. (1988) Genetics and demography in biological conservation. Science, 241, 1455-1460.

Matthew, B. (1989) The Iris. Batsford, London, UK.

MOE (Ministry of EnVironment) (2001) Lebanon State of the Environment Report. MOE/LEDO, Beirut, Lebanon.

MOF (Ministry of Finance) (undated) Direction des Sciences Topographiques, Circonscription Beyrouth \& Mont Liban, Casa de Kesserwan, Faraya - Délimitation cadastrale $n^{\circ} 86$. Ech. 1/100o. Ministry of Finance, Beirut, Lebanon.
Monty, A., SAaD, L. \& MAhy, G. (2006) Bimodal pollination system in rare endemic Oncocyclus irises (Iridaceae) of Lebanon. Canadian Journal of Botany, 84, 1327-1338.

MOPW (Ministry of Public Work) (undated) Direction de l'Urbanisme, Plan d'Urbanisme, Les Cèdres - Délimitation cadastrale. Ech. 1/200o. Ministry of Public Work, Beirut, Lebanon.

Mouterde, P. (1966) Nouvelle flore du Liban et de la Syrie. Tome 1. Imprimerie catholique, Beirut, Lebanon.

Oostermeijer, J.G.B., Luijten, S.H. \& Den Nijs, J.C.M. (2003) Integrating demographic and genetic approaches in plant conservation. Biological Conservation, 113, 389-398.

Post, G. (1933) Flora of Syria, Palestine and Sinai, Vol. 2. American University Press, Beirut, Lebanon.

Rix, M. (1997) Oncocyclus. In A Guide to Species Irises (ed. The Species Group of the British Iris Society), pp. 62-89. Cambridge University Press, Cambridge, UK.

S A AD, L. (2006) Etude écogéographique et biologie de la conservation des iris Oncocycles endémiques du Liban. PhD thesis, Faculté Universitaire des Sciences Agronomiques de Gembloux, Gembloux, France.

Samaha, L. (undated) Thematic Report on Mountain Ecosystems. MOE, Beirut, Lebanon.

Shmida, A., Fragman, O., Nathan, R., Shamir, Z. \& Sapir, Y. (2002) The Red Plants of Israel: a proposal of updated and revised list of plant species protected by the law. Ecologia Mediterranea, $28,55-64$.

Tan, A., Duman, H., Niksarli Inal, F., İnal, A. \& Karagoz, A. (2003) Ecosystem Conservation and Management for Threatened Plant Species Projects. 99/TR/065. Life Project. Ministry of Environment, Ankara, Turkey.

Tонме́, G. \& Toнmé, H. (2001) Two Thousand and One Flowers of Lebanon. UL Press, Beirut, Lebanon.

UNEP (2005) Global Strategy for Plant Conservation. Http:// www.cbd.int/gspc/ [accessed 20 May 2008].

Walter, K.S. \& Gillet, H.D. (eds) (1998) 1997 IUCN Red List of Threatened Plants. Compiled by the World Conservation Monitoring Centre. IUCN, Gland, Switzerland and Cambridge, UK.

West, W.A. (1963) New Oncocyclus irises. ASI Yearbook, 1963, $60-61$.

\section{Biographical sketches}

LAYLA SAAD carries out conservation biology research with a particular interest in plant endemism. She is currently working on the impacts of invasive plant species on native communities. SALMA N. TALHOUK is director the Initiative for Biodiversity Studies in Arid Regions at the American University of Beirut and is currently engaged in characterization of floristic diversity and in domestication trials as part of an interdisciplinary research project investigating the medicinal and horticultural potential of native Lebanese plant species. GRÉGORY MAHY has carried out research in community and population ecology from both an evolutionary perspective and in applied biodiversity conservation. He is currently leading a team focused on plant invasion, plant diversity in semi-natural habitats, and the applied population biology of endemics. 